Many members find banker's orders useful and they save the Society clerical work, stationery, and postage. Forms for deeds of covenant and banker's order will be sent by the Secretary on application.

Acknowledgements.-The Council desires to express its thanks to those who spoke and showed films at general meetings : to those who lectured on behalf of the Society, especially to Mr. C. E. E. Scott who not only spoke himself, but most generously used his car to carry lecturers : to the Natal Parks Board for the film "Heritage of Natal and Zululand" and to the Government of Uganda for "Wild Life in Uganda": to contributors to Oryx, not forgetting Mr. Ian MIenzies, for his valuable work on maps : and to many other helpers. Special thanks are due to the Zoological Society of London for the provision of office accommodation and for the unstinted help given by the Society's staff throughout the year.

\title{
THE AUDITORS' REPORT
}

To the Council and Members of the Fauna Preservation Socicty.

11 th February, 1955.

Accounts for tire Year ended 31st December, 1954

We have completed the audit of the Books and Accounts of the Society for the year ended 31st December, 1954, and report thereon as follows.

General Purposes Account

The Balance on this Account at the end of the year was $\mathfrak{E 6 , 2 1 8} 5 \mathrm{ss}$. $1 d$. after transferring $£ 110$ 12s. 8d. being excess of Income over Expenditure on the year's working and $£ 1,3448 s$. $7 d$. from the Life Membership Fund to which reference is made below.

We feel that we should point out that the surplus for the year arises after taking into account the receipt during the year of

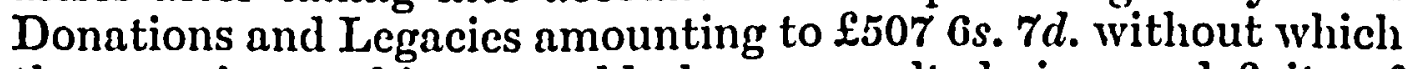
the year's working would have resulted in a deficit of $£ 306$ 13s. 11d.

The figure of $£ 110$ 12s. 8d. referred to above compares with $£ 1,02515 s$. $6 d$. in respect of the previous year and is after transferring $£ 100$ to the Secretary's 'Irnvelling Expenses $A$ ccount in accordance with the minutes of the Society. 'The reduction in the amount of surplus transferred is almost entirely accounted for by the reduction in the total amount received by way of Donations and Legacies. 


\section{BALANCE SHEET,}

1953.

$\mathcal{L}$

000 Sundry Creditors

85 Sunscriptions Received in Advance BaLANCE, being Excess of Assets over Liabilitics :-

Life Membership FundBalance at 1st January, 1054 -. Add Fees received $\begin{array}{lllll}\text { during year } & - & 110 & 0 & 0\end{array}$

Deduct Transfer to General Purposes Account, Subscriptions of deceased

4,085

\section{LianILITIES}

General Purposes Account-

seld Excess of Income over Expenditure for year

Secretary's Travelling Expenses Account (balance)
ransfer from Life Membership Fund, Subscriptions of decensed Life

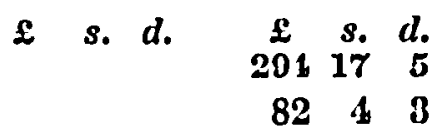

\begin{tabular}{llllll}
$1,34.4$ & 8 & 7 & & & \\
\hline
\end{tabular}

Balance at 1st January, 105.1 . . 4,071 \& 5

110128

01105

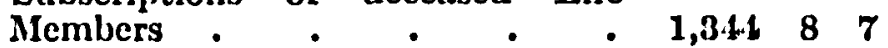

\&0, 6.10

We have examined the above Balance Sheet and the accompanying Income and Expenditure Account with the books and Accounts of the Society and certify them to be in accordance therewith. We have verified the Bank Balances and the Investments of the various Funds.

Finsiuny Cincus IIouse,

IV. B. Keian \& Co.

Blompield StneEt,

Charlered Accounlants.

LONDON, I..C. 2.

7lh February, 1955. 


\section{Ist DECEMBER, I954}

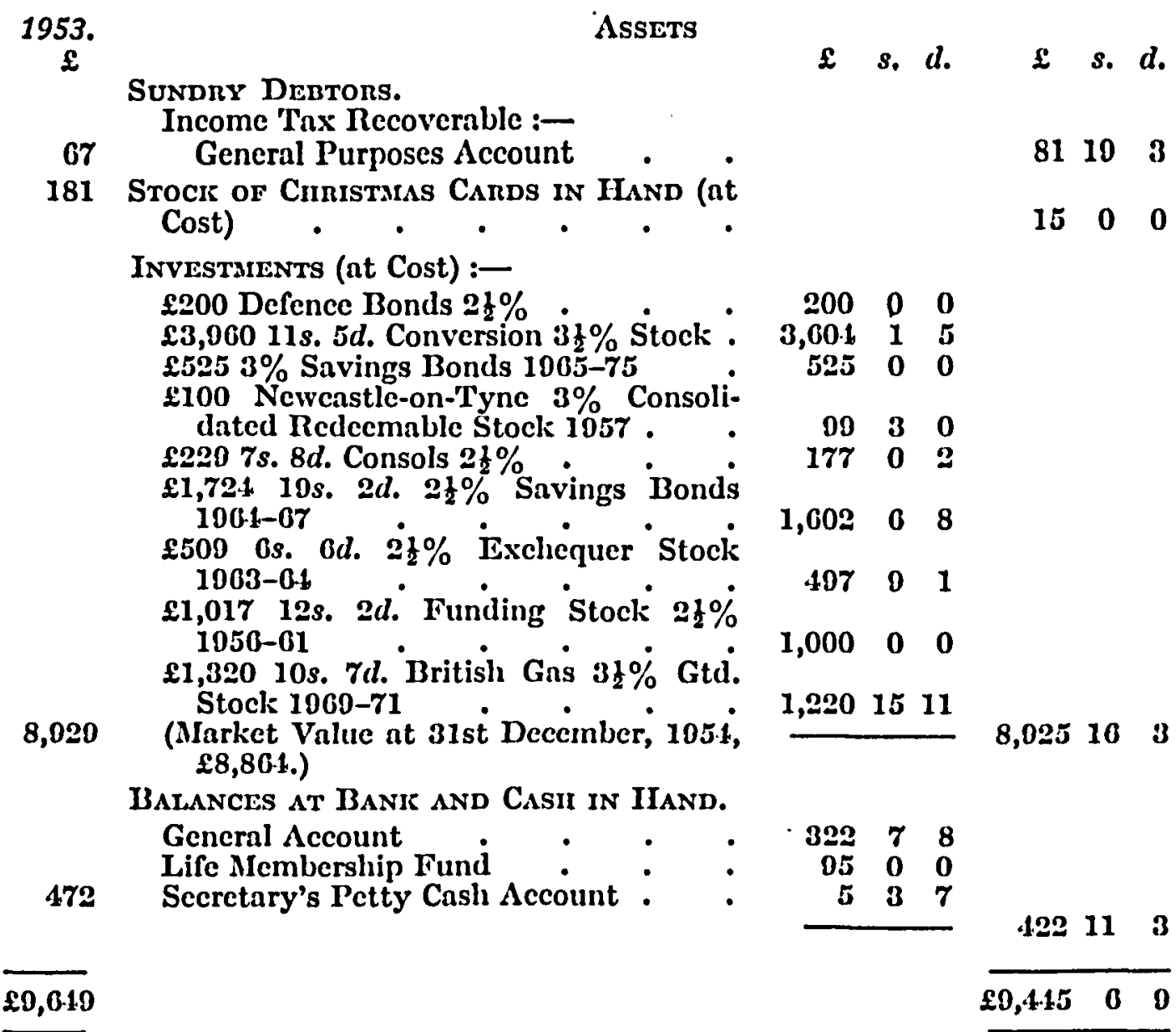




\section{INCOME AND EXPENDITURE ACCOUNT}

\section{GENERAL PURPOSES}

Expenditure

1953.

\section{⿷}

370 To Salarics

200

601

210

50

Sccretary

"Printing of Journal (3 Issues)

" Cost of Production-Christmas Cards .

"Stationery, etc. . . . .

" Rent of Omices . . . . .

Less Donation from Zoological Socicty .

85 "Omice Expenses, Insurance Stamps, etc..

75

12

30

100

31

100

40

13

4

$\mathbf{2 , 0 1 7}$

1,020
"Postages, etc.

"Refreshments at Meetings . . .

" IIire and Presentation of Films . .

"Assistant Secretary's Pension-Premium

"Accountancy and AuditAudit Fec, 1054 Accountancy, 1054

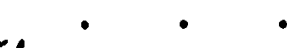

"Secretary's Travelling Expenses AccountGrant for yenr 1051

", Wnges of Game Guard, Mjeti, Nyasaland

"Suluscriptions :-

British Committec for International Nature Conservation

International Committec for Bird

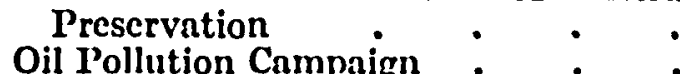

" Depreciation on Typewriter

„Balance-Excess of Income over Expenditure for year carricd to Balance Shect
\& s. d. $\quad \& \quad s, d$. $430 \quad 4 \quad 0$

$200 \quad 0 \quad 0$

$684 \quad 411$

$173 \quad 410$

$4814 \quad 6$

$250 \quad 0 \quad 0$

250000

$\begin{array}{lll}105 & 0 & 11\end{array}$

100221

$\begin{array}{lll}10 & 1 & 0\end{array}$

$\begin{array}{lll}70 & 10 & 8\end{array}$

$100 \quad 0 \quad 0$

10100

15150

550

31100

10000

4000

$\begin{array}{lll}3 & 0 & 0\end{array}$

550

10100

18150

$--$

$2,125 \quad 5 \quad 11$

110128 


\section{for the Year ended 3Ist December, I954.}

\section{ACCOUNT}

INCOMre

1953.

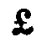

By Subscriptions-

\& s. $\quad$ d. $\quad \& \quad$ s. $d . \quad$ \& $\quad$ s. $d$.

14 Arrears • • • $\quad$ - $\quad$ - 21140

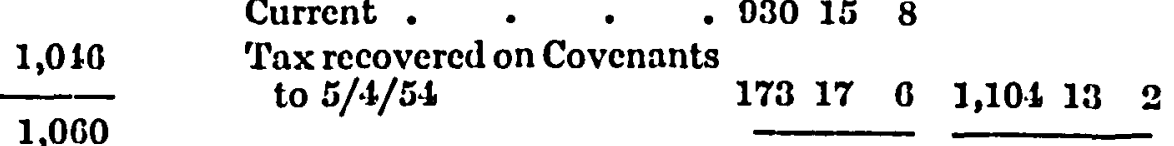




Number of Miembers and Arrears of Subscriptions

The number of Members on the Roll at 31st December, 1954, was 1,239 made up as follows :- .

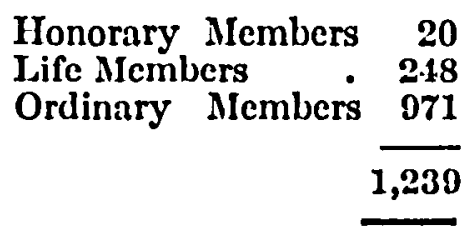

a decrease of one Honorary Member, and an increase of three Life Members and of nineteen Ordinary Members.

At 31st December, 1954, the number of Members in arrear for Subscriptions was 48 , made up as follows :-

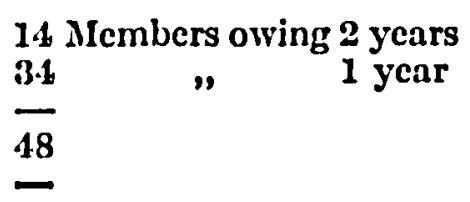

Life Mrembrensimp Fund

The balance to the credit of the Fund is now 22,850 . This is after crediting $\mathfrak{E 1 1 0}$ in respect of Life Membership subscriptions received during the year and transferring $£ 1,3448 s$. $7 d$. to the General Purposes Account which represents the accumulated value, over the past 25 years or so, of deceased Life Members' subscriptions.

The figure of $£ 2,850$ can therefore be taken as being the value of the subscriptions paid by actual live members at the end of the ycar. A similar adjustment will be made each year in future in respect of any decensed members.

\section{INVESTMENTS}

The total investments at 31st December, 1954, at Cost amounted to $£ 8,02516 s .3 d$. and the Market Value at that date

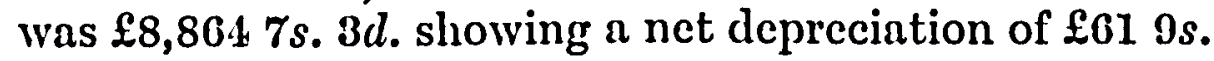

\section{Surplus}

The surplus of Assets over Liabilities at the end of the year

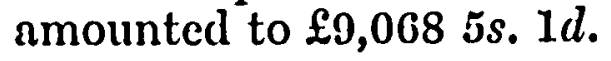

